\title{
PENGARUH KONSENTRASI NaOH TERHADAP RENDEMEN, KADAR AIR DAN KADAR ABU GELATIN CEKER ITIK (Anas Platyrhynchos Javanica)
}

\author{
The Effect of NaOH Concentration on Yield, Water and Ash Content of Duck \\ (Anas platyrhynchos Javanica) Feet Gelatin \\ Ramadhan Febriansyah $^{1)}$, Andry Pratama ${ }^{1)}$, Jajang Gumilar ${ }^{1)}$ \\ 1) Fakultas Peternakan Universitas Padjadjaran, Jl. Raya Bandung-Sumedang, Hegarmanah, Jatinangor, Kabupaten \\ Sumedang, Jawa Barat 45363 \\ Email: j.gumilar@unpad.ac.id
}

Diterima 15 Februari 2019 ; diterima pasca revisi 5 Maret 2019

Layak diterbitkan 1 April 2019

\begin{abstract}
Gelatin is a protein obtained from hydrolyzed collagen in animal skin and bones. Duck feet contained an abundant amount of collagens, yet has not been used properly, thus it has a potential to be used as an alternative for gelatin production. Gelatin is clasified as type A and $\mathrm{B}$. NaOH can be used during demineralization process in type B gelatin production. The aim of this research was to understand the effect and correlation of $\mathrm{NaOH}$ concentration on the gelatin rendemen, water content and ash content froom duck feet. The experiment was conducted experimentally using a completely randomized design (CRD), with 3 different $\mathrm{NaOH}$ concentrations $(P 1=3 \% ; P 2=5 \%$ and $P 3=7 \%)$. The results of the research were tested using variance analysis, then followed by Duncan's multiple range test and orthogonal polynomial test. The research showed that $\mathrm{NaOH}$ concentration gave different affect to the yield, water content and ash content of duck feet gelatin. The best NaOH concentration was at $3 \%$, which resulted in $4.77 \%$ yield, $7.20 \%$ water content, and $3.48 \%$ ash contents.
\end{abstract}

Keywords: NaOH concentration; rendemen; water content; ash content; gelatin 


\section{ABSTRAK}

Gelatin adalah suatu protein yang didapatkan dari hasil hidrolisis kolagen pada tulang dan kulit hewan. Ceker itik mengandung kolagen, jumlahnya banyak dan belum dimafaatkan dengan baik sehingga dapat dijadikan sebagai alternatif bahan baku gelatin. Gelatin dikelompokan menjadi gelatin tipe A dan B. NaOH dapat digunakan pada proses demineralisasi pembuatan gelatin tipe $B$. Penelitian ini bertujuan untuk mengetahui pengaruh konsentrasi dan pola hubungan $\mathrm{NaOH}$ terhadap rendemen, kadar air dan kadar abu gelatin ceker itik. Penelitian dilakukan secara eksperimen menggunakan Rancangan Acak Lengkap (RAL), dengan 3 perlakuan konsentrasi $\mathrm{NaOH}\left(P_{1}=3 \% ; P_{2}=5 \%\right.$ dan $P_{3}=$ 7\%). Hasil penelitian diuji menggunakan analisis ragam, dilanjutkan dengan uji jarak berganda Duncan dan uji polinomial orthogonal. Hasil penelitian menunjukkan bahwa konsentrasi $\mathrm{NaOH}$ berpengaruh nyata terhadap rendemen, kadar air dan kadar abu gelatin ceker itik. Konsentrasi NaOH terbaik pada kosentrasi 3\% dengan nilai rendemen 4,77\%, kadar air 7,20\% dan kadar abu 3,48\%.

Kata Kunci : Konsentrasi NaOH; rendemen; kadar air; kadar abu; gelatin

\section{PENDAHULUAN}

Peningkatan populasi itik beberapa tahun ini cukup signifikan, menurut Direktorat Jendral Peternakan dan Kesehatan Hewan (2016), statistik populasi itik dari tahun 2013 hingga 2016 mengalami peningkatan yang cukup pesat yaitu dari 43.709.900 ekor menjadi 47.424.151 ekor. Peningkatan populasi itik tersebut berdampak pada meningkatnya jumlah ceker itik sebanyak 819 ton menjadi 1.067 ton, hal ini menjadikan ketersediaan ceker Itik cukup melimpah untuk dimanfaatkan lebih lanjut. Konsumsi masyarakat akan itik sebagian besar dalam bentuk karkas meliputi daging bagian dada maupun paha, sedangkan ceker itik masih kurang diminati dan menjadi limbah. Pemanfaatan limbah ceker itik masih sangat terbatas dan belum banyak dilakukan, untuk meningkatkan nilai guna, ceker itik dapat diolah dan dimanfaatkan menjadi gelatin.
Gelatin dibuat dari bahan yang mengandung kolagen seperti kulit dan tulang babi, sapi, kambing, domba, ayam, dan itik. Produk gelatin saat ini sebagian besar dibuat dari kulit dan tulang sapi dan babi, namun masih jarang atau bahkan belum ada industri yang membuat gelatin dari ceker itik. Gelatin merupakan suatu jenis protein yang didapatkan dari hasil diekstraksi jaringan kolagen tulang, kulit, dan ligament (jaringan ikat) hewan yang diproses dengan larutan basa atau asam kuat sehingga ikatan kolagen terlepas dan menghasilkan gelatin (Ismeri dan Rihi, 2009).

Gelatin memiliki kemampuan membentuk gel, daya buih, dan emulsifikasi sehingga dapat digunakan pada berbagai industri seperti industri makanan, obat-obatan, fotografi, serta kosmetik. Gelatin juga sering digunakan sebagai stabiliser pada produk susu seperti es krim dan yogurt (Sarbon et al., 2015). Kemampuan unik yang dimiliki gelatin

How to cite:

*Corresponding author:

Jajang Gumilar

Email: j.gumilar@unpad.ac.id

Fakultas Peternakan Universitas Padjadjaran, Jl. Raya

Bandung-Sumedang, Hegarmanah, Jatinangor,

Kabupaten Sumedang, Jawa Barat 45363
Febriansyah, R., Pratama, A., \& Gumilar, J. (2019). Pengaruh Konsentrasi NaOH Terhadap Rendemen, Kadar Air dan Kadar Abu Gelatin Ceker Itik (Anas Platyrhynchos Javanica). Jurnal Ilmu dan Teknologi Hasil Ternak, 14 (1), 1-10 
adalah dapat membentuk gel yang reversible pada panas yang hampir sama dengan suhu tubuh manusia serta larut di dalam air (Gumilar dan Pratama, 2018).

Proses produksi gelatin secara umum dibagi menjadi tiga tahap. Tahap pertama adalah persiapan bahan baku untuk menghilangkan zat zat lain selain kolagen, tahap kedua merupakan tahap pembuatan gelatin yang dihasilkan dari perubahan kolagen, dan yang terakhir adalah tahap penyaringan dan pengeringan untuk memurnikan gelatin yang dihasilkan. Gelatin dibagi menjadi dua tipe yaitu tipe A dan tipe B. Tipe A menggunakan senyawa asam dan tipe $B$ menggunakan senyawa basa pada proses demineralisasi. Kualitas gelatin yang dihasilkan dipengaruhi oleh perbedaan bahan baku dan proses produksi yang dilakukan (Mad-Ali et al., 2016). Hasil penelitian penggunaan $\mathrm{NaOH}$ pada proses demineralisasi menghasilkan gelatin tipe B dengan warna kekuningan lebih gelap, viskositas, dan nilai $\mathrm{pH}$ lebih tinggi dari gelatin standar (Haris, 2008).

Penelitian Ananta (2017) pada pembuatan gelatin dari tulang ikan nila menggunakan basa natrium hidroksida $(\mathrm{NaOH})$ dengan konsentrasi $5 \%$ menghasilkan nilai rendemen sebesar $16,08 \%$. Adapun penelitian lainnya pembuatan gelatin dari ceker ayam menggunakan $\mathrm{NaOH}$ sebesar $5 \%$ pada proses demineralisasi yang dilakukan oleh Suryati dkk., (2015) menghasilkan nilai rendemen sebanyak 13,96\%, kadar air sebanyak $14,98 \%$ dan kadar abu sebanyak $3 \%$. Beberapa indikator dapat menjadi penentu efisiensi produksi dan kualitas gelatin, seperti rendemen, kadar air, dan kadar abu. Miwada dan Simpen (2008) menyatakan bahwa rendemen merupakan salah satu variabel dalam penelitian yang digunakan untuk mengetahui efektivitas metode yang digunakan, khususnya pada proses pembuatan suatu produk. Nilai rendemen semakin tinggi menunjukkan perlakuan yang diberikan pada penelitian tersebut semakin efisien. Kadar air gelatin menurut Winarno (2002) adalah berapa banyak kandungan air yang ada pada gelatin tersebut. Daya simpan gelatin dipengaruhi oleh kandungan air yang ada pada gelatin tersebut, hal ini terjadi karena aktivitas fisikokimia yang terjadi selama gelatin tersebut disimpan. Kadar abu pada bahan pangan menggambarkan banyaknya mineral yang ada pada bahan tersebut.

Perbedaan kandungan mineral pada sumber bahan baku serta proses demineralisasi pada saat pembuatan gelatin sangat menentukan tinggi rendahnya kandungan abu produk gelatin yang dihasilkan. Bahan baku serta metode pembuatan yang digunakan sangat menentukan kadar abu gelatin yang dihasilkan (Ockerman and Hansen, 2000). Penelitian ini memberikan informasi baru mengenai rendemen, kadar air dan kadar abu gelatin ceker itik pada penggunaan $\mathrm{NaOH}$. Tujuan dari penelitian ini yakni untuk mengetahui pengaruh konsentrasi $\mathrm{NaOH}$ terhadap rendemen, kadar air dan kadar abu serta perlakuan optimal untuk menghasilkan gelatin ceker itik terbaik.

\section{MATERI DAN METODE}

\section{Materi}

Bahan utama adalah ceker Itik Cihateup sebanyak 2,7 kg dari 90 ekor. Bahan lainya yaitu $\mathrm{NaOH} 3 \%, 5 \%$ dan $7 \%$ serta akuades. Alat yang digunakan adalah pisau, timbangan digital (Sartorius), timbangan analitik (Sartorius TE 214S), kompor gas, panci, waterbath (Julabo, TW 20), beaker glass $500 \mathrm{ml}$, oven (Lab Companion), Tanur (Thermo Scientific) cawan porselen, termometer, $\mathrm{pH}$ paper, saringan, loyang plastik, batang pengaduk, cawan krus, talenan, desikator, wadah plastik dan alumunium foil.

\section{Metode \\ Pembuatan gelatin}

Metode pembuatan gelatin dilakukan bedasarkan metode Said, dkk. (2011) dengan sedikit modifikasi. Adapun tahapan prosedur pembuatan gelatin dari ceker itik adalah sebagai berikut: Ceker itik yang 
telah didapatkan kemudian ditimbang beratnya dengan timbangan digital seberat 2,7 kg. Ceker itik dibersihkan terlebih dahulu dengan cara dicuci, setelah itu ceker itik direndam pada air bersuhu $90 \pm 3{ }^{\circ} \mathrm{C}$ selama 15 menit (degreasing), kemudian dipotong dengan ukuran $3 \mathrm{~cm}$ lalu ditimbang dengan berat masing-masing unit sebesar 150 g/unit dan dimasukan ke beaker glass.

Tahap demineralisasi dilakukan dengan cara menambahkan larutan $\mathrm{NaOH}$ $3 \%$, 5\% dan $7 \%$, perbandingan ceker itik dengan larutan 1:2 (b/v), kemudian ditutup dengan alumunium foil dan direndam selama 24 jam untuk menghilangkan kandungan kalsium dan garam-garam mineral yang terdapat di dalam ceker itik hingga ceker menjadi lunak atau disebut osein. Osein inilah yang mengandung kolagen dan sejumlah kecil protein lainnya. Osein tersebut lalu dicuci dengan aquades sampai $\mathrm{pH}$ netral (6-7). Osein yang dihasilkan kemudian diekstraksi dengan cara memasukan osein tersebut ke dalam beaker glass serta menambahkan aquades sebanyak $300 \mathrm{ml}$, ekstraksi osein dilakukan di dalam waterbath selama 5 jam dengan suhu $70^{\circ} \mathrm{C}$. Hasil ekstraksi kemudian disaring lalu dioven selama 48 jam dengan suhu $55 \pm 2^{\circ} \mathrm{C}$.

\section{Rendemen}

Uji kualitas gelatin yang dilakukan adalah uji rendemen, kadar abu, dan kadar air. Uji rendemen dilakukan dengan cara membandingkan berat akhir gelatin yang diperoleh dengan berat awal sampel yang akan diekstraksi menjadi gelatin (Miwada and Simpen, 2008). Rendemen gelatin dihitung dengan menggunakan rumus berikut ini:

Rendemen $(\%)=\frac{\text { Berat Gelatin }}{\text { Berat Sampel }} X 100 \%$

\section{Kadar air}

Kadar air diuji dengan cara mengeringkan terlebih dahulu cawan porselin yang akan digunakan pada suhu $105^{\circ} \mathrm{C}$ selama kurang lebih 1 jam, lalu disimpan di dalam desikator selama 30 menit kemudian cawan ditimbang sampai beratnya tetap (A). Sampel dimasukan ke dalam cawan kemudian ditimbang (B). Cawan beserta sampel dikeringkan di dalam oven dengan sugu $105^{\circ} \mathrm{C}$ selama 3 jam sampai dengan beratnya tetap. Sampel di dalam cawan didinginkan di dalam desikator selama 15 menit kemudian ditimbang hingga didapat berat yang tetap (C). Rumus yang digunakan untuk menghitung kadar air adalah sebagai berikut:

Kadar Air $(\%)=\frac{B-(C-A)}{B} X 100 \%$

\section{Kadar abu}

Kadar abu diuji menggunakan metode AOAC, dengan cara cawan porselin untuk pengabuan dikeringkan di dalam oven dengan suhu $105^{\circ} \mathrm{C}$ selama 1 jam kemudian didinginkan di dalam desikator selama 15 menit. Cawan tersebut ditimbang dan dipanaskan kembali sampai didapat berat yang stabi. Sebanyak $2 \mathrm{~g}$ sampel dimasukkan ke dalam cawan porselin untuk pengabuan kemudian dipijarkan sampai dengan tidak kelaur asap lagi. Cawan dan sampel kemudian dimasukkan ke dalam tanur sengan suhu $600^{\circ} \mathrm{C}$ selama 6 jam. Cawan dan sampel yang sudah menjadi abu kemudian didinginkan di dalam desikator untuk kemudian di timbang dan di analisa. Penghitungan kadar abu dihitung menggunakan rumus berikut:

Kadar abu $(\%)=\frac{\text { Berat } A b u}{\text { Berat Sampel }} \times 100 \%$

\section{Analisis statistika}

Rancangan yang digunakan pada penelitian ini adalah Rancangan Acak Lengkap (RAL) pola searah. Penelitian pembuatan gelatin ceker itik ini menggunakan berbagai konsentrasi $\mathrm{NaOH}$ sebesar 3\% sebagai (P1), 5\% sebagai (P2), dan 7\% sebagai (P3), masing-masing perlakuan diberikan ulangan sebanyak 6 kali. 
Pengaruh perlakuan konsntrasi $\mathrm{NaOH}$ terhadap rendemen, kadar abu, dan kadar air dianalisis menggunakan analisis varian, uji lanjut menggunakan Uji Jarak Berganda Duncan untuk mengetahui perbedaan dari setiap perlakuan, serta Uji Polinomial Orthogonal digunaka untuk mengetahui perlakuan yang optimal dan untuk mengetahui kecenderungan antar perlakuan.

\section{HASIL DAN PEMBAHASAN}

\section{Pengaruh Konsentrasi $\mathrm{NaOH}$ terhadap Rendemen Ceker Itik}

Hasil penelitian dapat dilihat pada Tabel 1. Perbandingan antara berat awal bahan baku (ceker itik) yang akan diproses dengan berat akhir produk (gelatin) yang dihasilkan disebut dengan rendemen. Rendemen dinyatakan dalam satuan persen. Data hasil penelitian yag disajikan pada
Tabel 1 menjelaskan bahwa rata-rata rendemen gelatin ceker itik berkisar antara $2,11 \%$ hingga $4,76 \%$. Nilai rata-rata rendemen gelatin ceker itik tertinggi pada konsentrasi $\mathrm{NaOH} 3 \%\left(\mathrm{P}_{1}\right)$ sebesar 4,76\% dan terendah pada konsentrasi $\mathrm{NaOH} 5 \%$ $\left(\mathrm{P}_{2}\right)$ sebesar $2,11 \%$.

Hasil uji statistika menggunakan analisis ragam menggambarkan bahwa konsentrasi $\mathrm{NaOH}$ berpengaruh nyata $(\mathrm{P}<0,05)$ terhadap rendemen gelatin ceker itik, uji lanjut menggunakan Uji Jarak Berganda Duncan untuk mengetahui perbedaan antar perlakuan menjelaskan bahwa perlakuan konsentrasi $\mathrm{NaOH} 3 \%$ $\left(\mathrm{P}_{1}\right)$ berbeda nyata $(\mathrm{P}<0,05)$ lebih tinggi dibandingkan konsentrasi $\mathrm{NaOH} 5 \%\left(\mathrm{P}_{2}\right)$, dan konsentrasi $\mathrm{NaOH} 7 \%\left(\mathrm{P}_{3}\right)$. Kasankala et al., (2007) menyatakan bahwa proses ekstraksi protein kolagen mempengaruhi rendemen yang dihasilkan dari suatu proses produksi gelatin.

Tabel 1. Pengaruh Berbagai Konsentrasi $\mathrm{NaOH}$ Terhadap Nilai Rendemen, Kadar Air dan Kadar Abu Gelatin Ceker Itik

\begin{tabular}{lccc}
\hline \multirow{2}{*}{ Peubah } & \multicolumn{3}{c}{ Perlakuan } \\
\cline { 2 - 4 } & $\mathrm{P}_{1}$ & $\mathrm{P}_{2}$ & $\mathrm{P}_{3}$ \\
\hline Rendemen (\%) & $4,77^{\mathrm{a}}$ & $2,11^{\mathrm{b}}$ & $3,84^{\mathrm{b}}$ \\
Kadar Air (\%) & $7,20^{\mathrm{a}}$ & $10,44^{\mathrm{b}}$ & $10,96^{\mathrm{b}}$ \\
Kadar Abu (\%) & $3,48^{\mathrm{a}}$ & $5,80^{\mathrm{b}}$ & $6,22^{\mathrm{c}}$ \\
\hline
\end{tabular}

Keterangan: Superscript yang berbeda ke arah baris menunjukkan perberbedaan nyata $(\mathrm{P}<0,05)$ antar perlakuan.

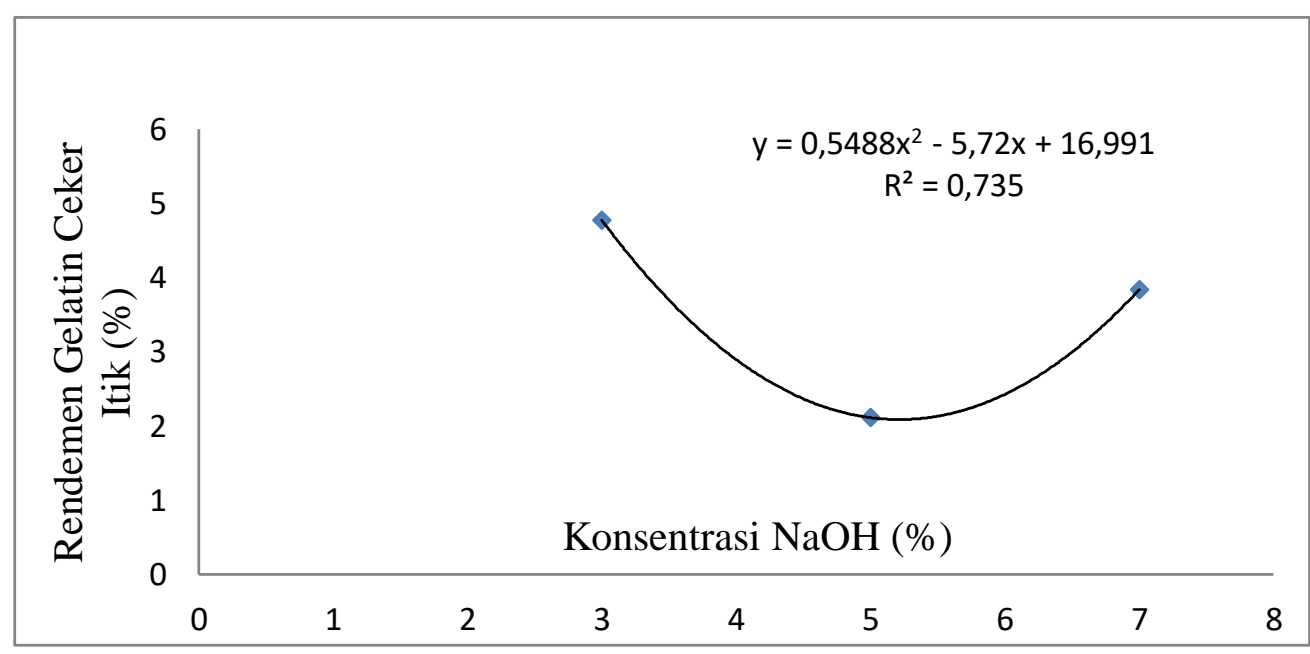

Gambar 1. Grafik Polinomial Orthogonal Rendemen Gelatin Ceker Itik 
Kolagen berbentuk rantai triple helix akan terhidrolisis oleh ion $\mathrm{OH}^{-}$menjadi rantai tunggal dengan gugus $\mathrm{x}$-GlysinProlin-Hidroksi Prolin-Glysin-y. Semakin tinggi konsentrasi $\mathrm{NaOH}$ maka kandungan basa $\left(\mathrm{OH}^{-}\right)$semakin banyak sehingga protein terhidrolisis lebih sempurna menjadi komponen yang lebih kecil lagi hal ini dapat menyebabkan gelatin tidak dapat diperoleh lagi pada hasil ekstraksi tersebut. Efiseinsi produksi untuk menghasilkan produk dengan jumlah yang diharapkan dapat dilihat dengan nilai rendemen (Amiruddin 2007).

Pengujian polinomial orthogonal dilakukan untuk mengetahui perlakuan yang optimal terhadap rendemen gelatin ceker itik. Hasil dari uji polinomial orthogonal disajikan pada Gambar 1. Disimpulkan bahwa grafik berbentuk kuadratik dengan persamaan $\mathrm{y}=0,5488 \mathrm{x}^{2}-$ $5,72 x+16,991$ dengan $R^{2}=0,735$. Hasil pada grafik menunjukkan koefisien determinasi sebesar $73,5 \%$, hal ini berarti kosentrasi $\mathrm{NaOH}$ berpengaruh terhadap nilai rendemen gelatin ceker itik sebesar $73,5 \%$ dimana variabel independen memberikan seluruh informasi yang dibutuhkan untuk memprediksi variabel dependen (Ghozali, 2012).

Hasil perhitungan bedasarkan Gambar 1, menunjukkan perlakuan yang optimal ialah dengan konsentrasi $\mathrm{NaOH}$ $3 \%\left(\mathrm{P}_{1}\right)$ dihasilkan nilai rendemen tertinggi sebesar $4,76 \%$. Rendemen hasil penelitian ini mirip dengan hasil penelitian gelatin dari kaki itik sebesar 3,65 - 5,75\% (Abedinia et al., 2017).

\section{Pengaruh Konsentrasi $\mathrm{NaOH}$ terhadap Kadar Air Gelatin Ceker Itik}

Tabel 1 menggambarkan rata-rata kadar air gelatin ceker itik antara 7,20\% hingga $10,95 \%$. Nilai rata-rata kadar air gelatin ceker itik tertinggi ditunjukan pada konsentrasi $\mathrm{NaOH} 7 \%\left(\mathrm{P}_{3}\right)$ sebesar 10,95\%, kemudian menurun pada konsentrasi $\mathrm{NaOH}$ $5 \% \quad\left(\mathrm{P}_{2}\right)$ sebesar $10,43 \%$ dan pada konsentrasi $\mathrm{NaOH} 3 \%$ sebesar 7,20\% $\left(\mathrm{P}_{1}\right)$. Hasil analisis ragam menunjukkan bahwa konsentrasi $\mathrm{NaOH}$ memberikan pengaruh nyata $(\mathrm{P}<0,05)$ terhadap kadar air gelatin ceker itik. Uji Jarak Berganda Duncan digunakan untuk menguji perbedaan antar perlakuan. Rata-rata kadar air gelatin ceker itik tertinggi pada konsentrasi $\mathrm{NaOH} 7 \%$ $\left(\mathrm{P}_{3}\right)$ berbeda nyata lebih tinggi $(\mathrm{P}<0,05)$ dibandingkan dengan konsentrasi $\mathrm{NaOH}$ $3 \%\left(\mathrm{P}_{1}\right)$, sedangkan berbeda tidak nyata $(\mathrm{P}>0,05)$ apabila dibandingkan dengan konsentrasi $\mathrm{NaOH} 5 \%\left(\mathrm{P}_{2}\right)$.

Nilai rata-rata kadar air meningkat seiring dengan meningkatnya konsentrasi $\mathrm{NaOH}$, semakin meningkat konsentrasi $\mathrm{NaOH}$ menyebabkan larutan perendam proses demineralisasi menjadi lebih basa sehingga kolagen lebih banyak yang tehidrolisis dan ikatannya menjadi lebih lemah, hal ini sesuai dengan peryataan Astawan dan Aviana (2003) bahwa peningkatan kadar air gelatin ini disebabkan oleh struktur kolagen yang semakin terbuka dengan ikatan yang lemah, sehingga daya ikat air pada gelatin juga kurang kuat.

Peningkatan konsentrasi $\mathrm{NaOH}$ membuat banyak basa yang terdifusi dalam jaringan ceker itik sehingga struktur kolagen semakin terbuka dan menghasilkan struktur gelatin dengan ikatan lemah, hal ini yang menyebabkan kadar air gelatin ceker itik meningkat. Hasil rata-rata kadar air gelatin masih memenuhi mutu Standar Nasional Indonesia yaitu kadar air maksimum gelatin sebesar $16 \%$.

Pengujian polinomial orthogonal dilakukan untuk mengetahui perlakuan yang optimal terhadap kadar air gelatin ceker itik. Hasil dari uji polinomial orthogonal disajikan pada Gambar 2. Disimpulkan bahwa grafik berbentuk linear dengan persamaan $\mathrm{y}=0,94 \mathrm{x}+4,8333$ dengan $R^{2}=0,8515$. Hasil pada grafik menunjukkan koefisien determinasi sebesar $85,15 \%$, hal ini berarti kosentrasi $\mathrm{NaOH}$ berpengaruh terhadap nilai kadar air sebesar $85,15 \%$ dimana seluruh informasi yang dibutuhkan dalam memprediksi variabel dependen diberikan oleh variabel independen. Berdasarkan Gambar 2, 
menunjukkan bahwa perlakuan yang optimal ialah pada konsentrasi $\mathrm{NaOH} \mathrm{3 \%}$ $\left(\mathrm{P}_{1}\right)$ dengan rata-rata kadar air sebesar $7,20 \%$.

\section{Pengaruh Konsentrasi NaOH Terhadap Kadar Abu Gelatin Ceker Itik}

Tabel 1 menunjukkan bahwa rata-rata kadar abu gelatin ceker itik berkisar antara $3,48 \%$ hingga $6,22 \%$. Nilai rata-rata kadar abu terendah yakni pada konsentrasi $\mathrm{NaOH}$ $3 \% \quad\left(\mathrm{P}_{1}\right)$ sebesar 3,48\%, kemudian meningkat pada konsentrasi $\mathrm{NaOH} 5 \%\left(\mathrm{P}_{2}\right)$ menjadi $5,80 \%$ dan pada konsentrasi $\mathrm{NaOH}$ $7 \%\left(\mathrm{P}_{3}\right)$ menjadi $6,22 \%$. Nilai kadar abu suatu bahan menggambarkan jumlah mineral yang terkandung dalam bahan tersebut. Penghilangan mineral dalam proses ekstraksi gelatin terjadi pada saat demineralisasi. Proses demineralisasi sangat menentukan besar kecilnya kadar abu pada gelatin. Demineralisasi pada penelitian ini dilakukan dengan perendaman dalam larutan basa $(\mathrm{NaOH})$ selama 24 jam.

Hasil uji ragam menyimpulkan bahwa konsentrasi $\mathrm{NaOH}$ memberikan pengaruh nyata $(\mathrm{P}<0,05)$ terhadap kadar abu gelatin ceker itik. Uji Jarak Berganda Duncan digunakan untuk mengetahui perbedaan diantara perlakuan. Hasil uji Duncan menunjukkan bahwa perlakuan konsentrasi $\mathrm{NaOH} 3 \%\left(\mathrm{P}_{1}\right)$ berbeda nyata lebih rendah $(\mathrm{P}<0,05)$ dibandingkan dengan konsentrasi $\mathrm{NaOH} 5 \%\left(\mathrm{P}_{2}\right)$ dan konsentrasi $\mathrm{NaOH} 7 \%\left(\mathrm{P}_{3}\right)$.

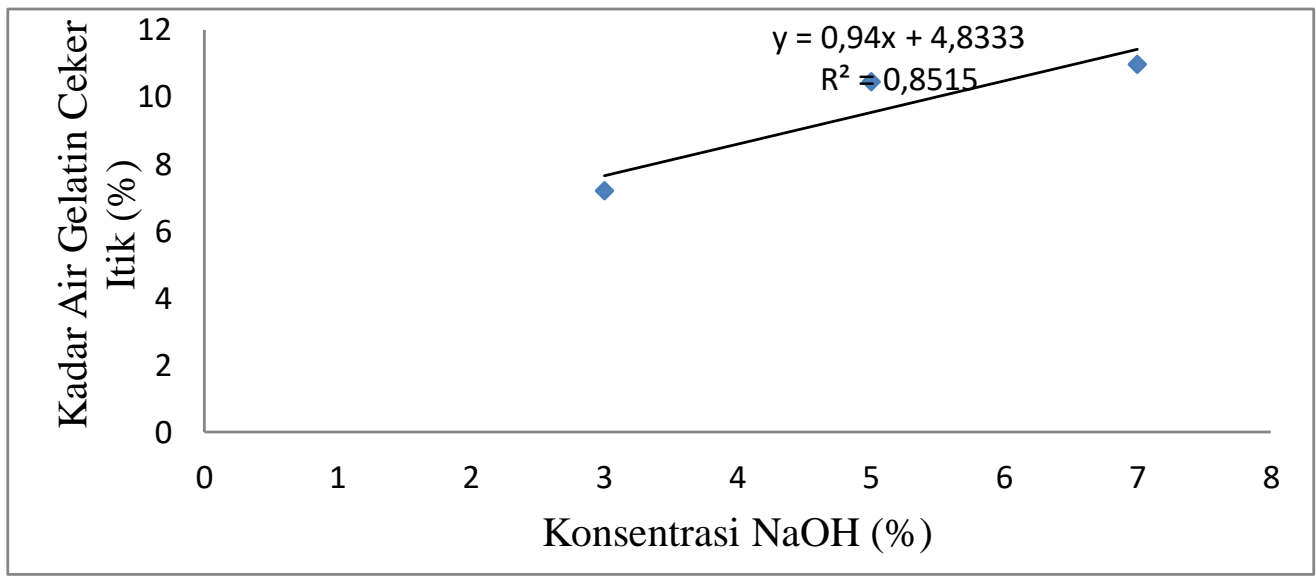

Gambar 2. Grafik Polinomial Orthogonal Kadar Air Gelatin Ceker Itik.

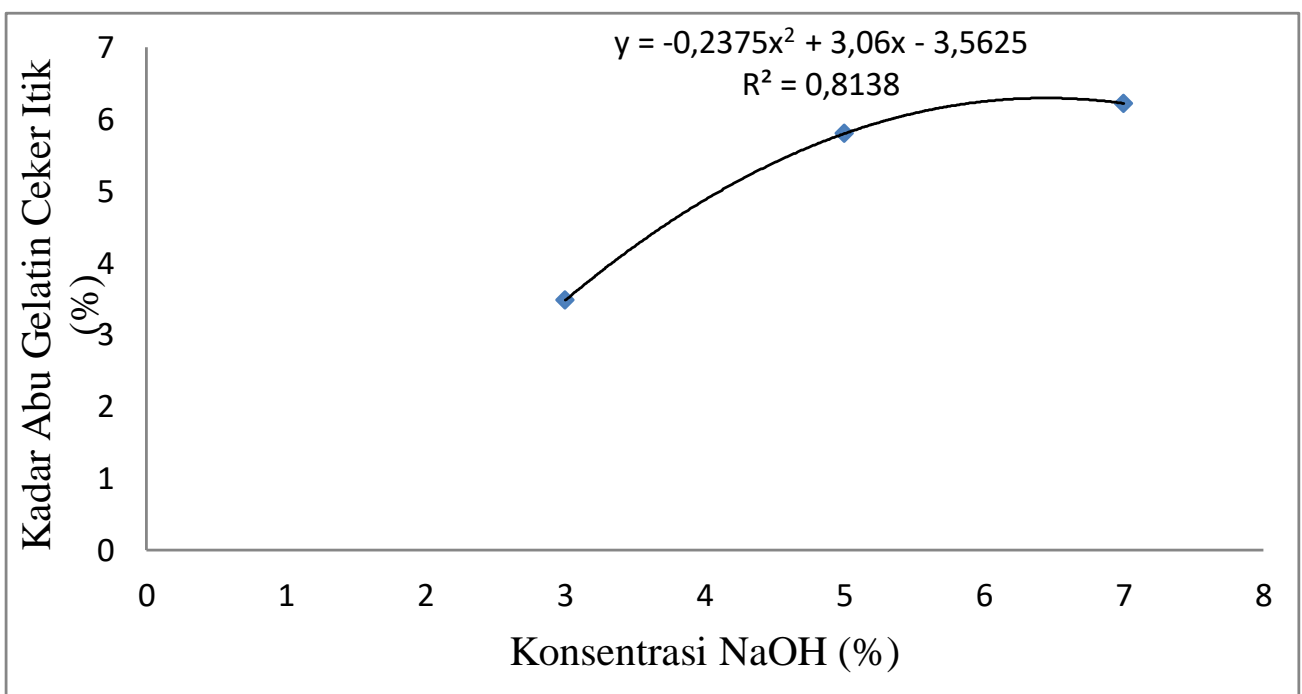

Gambar 3. Grafik Polinomial Orthogonal

Kadar Air Gelatin Ceker Itik. 
Konsentrasi $\mathrm{NaOH} 5 \%\left(\mathrm{P}_{2}\right)$ berbeda nyata lebih rendah $(\mathrm{P}<0,05)$ dibandingkan dengan konsentrasi $\mathrm{NaOH} 7 \%\left(\mathrm{P}_{3}\right)$. Nilai kadar abu semakin meningkat seiring dengan meningkatnya konsentrasi $\mathrm{NaOH}$, hal ini sesuai dengan peryataan GomesGuillen et al., (2002) yang menyatakan bahwa besar kecilnya kadar abu gelatin sangat dipengaruhi oleh konsentrasi bahan kimia, sehingga bahan kimia yang berkonsentrasi tinggi memungkinkan terjadinya hidrolisis yang berlebihan hal ini menyebabkan hilangnya molekul protein dan mengendapnya mineral yang tidak dibutuhkan. Puspawati dkk. (2012) menyatakan bahwa mineral yang tidak dibutuhkan ini akan menyebabkan kadar abu yang tinggi pada gelatin. Hasil ratarata kadar abu gelatin yang direndam pada konsentrasi $\mathrm{NaOH} \quad 3 \% \quad\left(\mathrm{P}_{1}\right)$ masih mendekati kualitas kadar abu yang ditetapkan pada Standar Nasional Indonesia mengenai standar mutu gelatin dimana batas maksimum kadar abu gelatin yaitu $3,25 \%$. Pengujian polinomial orthogonal dilakukan untuk mengetahui perlakuan yang optimal terhadap kadar abu gelatin ceker itik. Hasil dari uji polinomial orthogonal disajikan pada Gambar 3. disimpulkan bahwa grafik berbentuk kuadratik dengan persamaan $\mathrm{y}=-0,2375 \mathrm{x}^{2}$ $+3,06 \mathrm{x}-3,5625$ dengan $\mathrm{R}^{2}=0,8138$.

Hasil pada grafik menunjukkan koefisien determinasi sebesar $81,38 \%$, hal ini berarti konsentrasi $\mathrm{NaOH}$ berpengaruh terhadap nilai kadar abu sebesar $81,38 \%$ dimana variabel-variabel independen memberikan pengaruh terhadap variablevariabel dependen sebesar $81,38 \%$ dan sisanya dipengaruhi oleh variabel ang tidak diukur dalam penelitian ini. Bedasarkan Gambar 3. Menunjukkan perlakuan paling optimal ialah perendaman menggunakan konsentrasi $\mathrm{NaOH}$ sebanyak $3 \% \quad\left(\mathrm{P}_{1}\right)$ dengan rata- rata kadar abu terendah dihasilkan dengan sebesar 3,48\%.

\section{KESIMPULAN}

Penggunaan berbagai konsentrasi $\mathrm{NaOH}$ memberikan efek yang berbeda terhadap rendemen, kadar air dan kadar abu gelatin ceker itik. Penggunaan $\mathrm{NaOH}$ terbaik yaitu pada konsentrasi 3\% yang menghasilkan gelatin ceker itik dengan rendemen sebesar 4,77\%, kadar air 7,20\% dan kadar abu 3,48\%. Pola hubungan antar pelakuan bervariasi. Rendemen gelatin mengikuti pola hubungan kuadratik dengan persamaan $\mathrm{y}=0,5488 \mathrm{x}^{2}-5,72 \mathrm{x}+16,991$, $\mathrm{R}^{2}=0,735$. Kadar air gelatin mengikuti pola hubungan liniear dengan persamaan y $=0,94 \mathrm{x}+4,8333, \mathrm{R}^{2}=0,8515$. Kadar abu gelatin mengikuti pola hubungan $\mathrm{y}=$ $0,2375 x^{2}+3,06 x-3,5625, R^{2}=0,8138$.

\section{UCAPAN TERIMAKASIH}

Penelitian ini didanai oleh Program Hibah Internal Universitas Padjadjaran, oleh karena itu kami mengucapkan terimakasih yang sebesar-besarnya kepada Rektor Universitas Padjadjaran.

\section{DAFTAR PUSTAKA}

Abedinia, A., Ariffin, F., Huda, N., \& Nafchi, A. M. (2017). Extraction and characterization of gelatin from the feet of pekin duck ( anas platyrhynchos domestica ) as affected by acid, alkaline, and enzyme pretreatment. international journal of biological macromolecules, 98, 586-594. https://doi.org/10.1016/j.ijbiomac.2017.01.139

Amirudin, M. (2007). pembuatan dan analisis karakteristik gelatin dari tulang ikan tuna (thunnus albacares) (tesis). bogor: fakultas teknologi pertanian institut pertanian bogor. 
Ananta, L. (2017). optimalisasi gelatin tulang ikan nila melalui praperlakuan dan jenis larutan ekstraksi dalam pembuatan edible film (thesis). Semarang: Fakultas Teknologi Pertanian Universitas Katolik Soegijapranata.

Astawan, M., \& Aviana, T. (2003). Pengaruh jenis larutan perendam serta metode pengeringan terhadap sifat fisik, kimia, dan fungsional gelatin dari kulit cucut. Jurnal Teknologi Dan Industri Pangan , 14(1), 7-13.

Dirjen Peternakan Dan Kesejahteraan Hewan. (2016). statistik peternakan dan kesehatan hewan. direktorat jendral peternakan dan kesehatan hewan. Jakarta: Direktorat Jendral Peternakan Dan Kesehatan Hewan Kementrian Pertanian Indonesia.

Ghozali. (2012). aplikasi analisis multivariate dengan program ibm spss 20. Semarang: Badan Penerbit Universitas Diponegoro.

Gómez-guillén, M., Turnay, J., FernándezDíaz, M., Ulmo, N., Lizarbe, M., \& Montero, P. (2002). Structural and physical properties of gelatin extracted from different marine species: a comparative study. Food Hydrocolloids, 16(1), 25-34. https://doi.org/10.1016/s0268-005x(01)00035-2

Gumilar, J., \& Pratama, A. (2018). Produksi dan karakteristik gelatin halal berbahan dasar usus ayam. Jurnal Teknologi Industri Pertanian, 28(1), 75-81. https://doi.org/10.24961/j.tek.ind.pert.2018.28.1.75

Haris. (2008). Pemanfaatan Limbah Tulang Ikan Nila Sebagai Gelatin dan Pengaruh Lama Penyimpanan Pada Suhu Ruang (Thesis). Bogor: Institut Pertanian Bogor.
Ismeri, R. S., \& Rihi, S. (2009). Optimalisasi Mutu dan Kualitas Gelatin Ikan dengan menggunakan Enzim Transglutaminase sebagai Pedorong Produksi Gelatin Dalam Negeri. Bogor: Institut Pertanian Bogor.

Kasankala, L. M., Xue, Y., Weilong, Y., Hong, S. D., \& He, Q. (2007). Optimization of gelatine extraction from grass carp (Catenopharyngodon idella) fish skin by response surface methodology. Bioresource Technology, 98(17), 3338-3343. https://doi.org/10.1016/j.biortech.2006.03.019

Mad-Ali, S., Benjakul, S., Prodpran, T., \& Maqsood, S. (2016). Interfacial properties of gelatin from goat skin as influenced by drying methods. $L W T, 73$, 102-107. https://doi.org/10.1016/J.LWT.2016.05.048

Miwada, S., \& Simpen. (2008). Peningkatan Potensi Ceker Broiler Hasil Sampingan Dari Tempat Pemotongan Ayam (TPA) Menjadi Gelatin Dengan Menggunakan Ekstraksi Terkombinasi. Denpasar: Fakultas Peternakan Universitas Udayana.

Ockerman, H. W., \& Lue, H. C. (2000). Animal by Product Processing and Utilization. USA: CRC Press.

Puspawati, N. M., Simpen, I. N., \& Miwada, I. N. S. (2012). Isolasi gelatin dari kulit kaki ayam broiler dan karakterisasi gugus fungsinya dengan spektrofotometri FTIR. Jurnal Kimia (Journal of Chemistry), 6(1), 79-87.

Said, M. I., Triatmojo, S., Erwanto, Y., \& Fudholi, A. (2012). Karakteristik Gelatin kulit kambing yang diproduksi melalui proses asam dan basa. AgriTECH, 31(3), 190-200. https://doi.org/10.22146/agritech.9744 
Sarbon, N. M., Badii, F., \& Howell, N. K. (2015). The effect of chicken skin gelatin and whey protein interactions on rheological and thermal properties. Food Hydrocolloids, 45, 83-92. https://doi.org/10.1016/J.FOODHYD.2014.10.008
Suryati, Nasrul, Z. A., Meriatna, \& Suryani. (2015). Pembuatan dan karakteristik gelatin dari ceker ayam dengan proses hidrolisis. Jurnal Teknologi Unimal, 4(2), 66-79.

Winarno, F, G. (2002). Kimia Pangan dan Gizi. Jakarta: PT Gramedia Pustaka Utama. 